\title{
Н.М. БАЧИНСКИЙ. РЕМОНТ МАВЗОЛЕЯ ХОДЖИ АХМЕДА ЯСАВИ в 1928 году
}

\author{
(ㄷ) 2019 г. Ю.А. Ёлгин
}

В 1928-1930-х годах проводился значительный ремонт мавзолея Ходжи Ахмеда Ясави в г. Туркестане, носивший характер экстренных противоаварийных мероприятий. Основной объём ремонтных и исследовательских работ пришёлся на 1928 г. Возглавил их исследователь среднеазиатского зодчества и практик реставрационного дела архитектор Н.М. Бачинский, командированный с этой целью в г. Туркестан Ленинградскими Государственными реставрационными мастерскими. На основании докладов и отчётов Н.М. Бачинского, а также других документов, хранящихся в Центральном Государственном архиве Республики Узбекистан (Ташкент), раскрывается ход и содержание ремонта, являющегося почти неизученной страницей в истории ремонтов, реставрации и изучения мавзолея Ясави.

Ключевые слова: археологические исследования, мавзолей Ходжи Ахмеда Ясави, Н.М. Бачинский, М.Е. Массон, ремонт, Ак-Сарай, кудук-хана, мечеть, пештак

1920-е годы - это период в истории изучения и ремонтов мавзолея Ходжи Ахмеда Ясави в г. Туркестане, когда, конечно далеко не в полной мере, были реализованы научноисследовательские и ремонтноохранительные начинания первого десятилетия XX в. Они были предприняты, главным образом, археологом и востоковедом Н.И. Веселовским и туркестанскими инженерами и архитекторами В.С. Гейнцельманом и С.Г. Маллицким при участии многих членов Туркестанского кружка любителей археологии. Основной объём этих работ приходится на 1928 г. Впервые в истории памятника они сопровождались фрагментарными археологическими раскопками, осу- ществлёнными М.Е. Массоном. Возглавлял эту экспедицию архитектор H.М. Бачинский.

Об этом замечательном исследователе зодчества Средней Азии и практике реставрационного дела имеется очень мало сведений. Неизвестна даже точная дата его смерти. Мы располагаем лишь краткой биографической справкой, составленной петербургским археологом и историографом Г.В. Длужневской.

Николай Михайлович Бачинский (1886 - после 1950) был уроженцем Орловской губернии. В 1914 г. окончил Реальное училище и был призван в армию. В 1915-1918 гг. после ранения находился в плену в Германии. В 1918-1924 гг. учился в 
Берлине. Затем вернулся на родину. В 1927 г. был принят в Ленинградские Государственные реставрационные мастерские (ЛГРМ). Тогда же начались его экспедиционные поездки в Среднюю Азию. В 1927-1928 гг. он занимался реставрацией знаменитой Буранинской башни - минарета XI в. на Буранинском городище в Киргизии. По линии ЛГРМ был командирован в 1928 г. в г. Туркестан для проведения ремонтных работ на мавзолее Ходжи Ахмеда Ясави [Длужневская, 2011, с. 161]. О том, что именно ЛГРМ рекомендовали его «на это дело», Н.М. Бачинский писал в

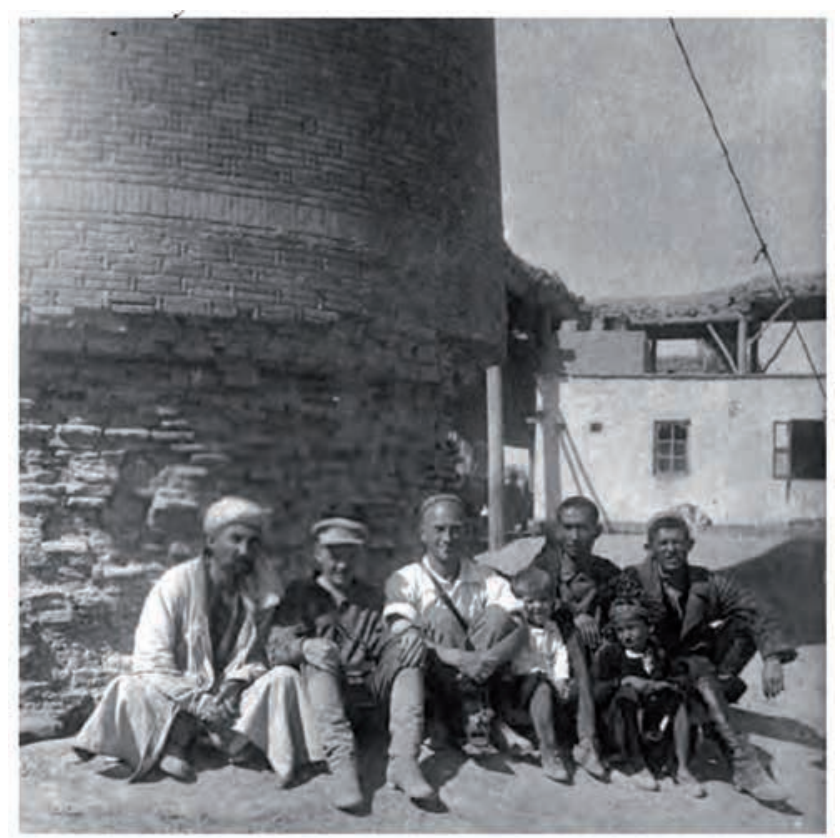

Рис.1. Бухара. Медресе Кукельдаш. Второй слева В.А. Шишкин. Рядом с ним архитектор Н.М. Бачинский. 1930-е г2.

Fig.1. Bukhara. Kukeldash Madrasah. Second left V.A. Shishkin. Next to him, architect N.M. Bachinsky. 1930 одном из писем к коллегам от 20 февраля 1929 г. [ЦГА РУз., ф. Р2810, оп. 1, д. 114, л. 3].

После закрытия ЛГРМ с 1929 по 1933 год работал в Бухарском Комитете по делам музеев, охраны памятников старины и искусства (подразделение Узкомстариса), где участвовал в реставрации многих памятников истории и культуры Средней Азии. Возвратившись в Ленинград в 1933-1934 гг., стал сверхштатным сотрудником ГАИМК, а в 1934 г. - сотрудником Института археологических технологий (ИАТ). В 1938 г. по поручению ГАИМК совершил поездку в Ашхабад.

В экспедициях в Среднюю Азию с 1928 г. участвовал регулярно. В 1937 г. переехал в Москву. Защитил докторскую диссертацию «Искусство старых зодчих Туркмении (материа-

лы и приёмы старых туркменских зодчих IX-XIIIвв.)» [Длужневская, 2011, c. 161].

Работы Н.М. Бачинского в г. Туркестане никогда не становились предметом отдельного исследования. Их, конечно, принимали во внимание практики-реставраторы последующих десятилетий, но в историографических обзорах по памятнику Н.М. Бачинскому уделялось не более двух-трёх строк. Между тем его вклад в изучение и ремонты мавзолея Ходжи Ахмеда Ясави, сделанный в кратчайшие сроки, довольно в значительной мере компенсировал несбывшиеся начинания и неосуществлённые проекты по спасению мавзолея, предпринятые колониальной администрацией Туркестанского края в 1880-1910 гг.

Туркестанской командировке H.М. Бачинского предшествовал ряд 
организационных моментов и мелких ремонтов. В 1925 г. состоялась вторая экспедиция Средазкомстариса в г. Туркестан для обследования мавзолея Ходжи Ахмеда Ясави [ЦГА РУз., ф. Р2406, оп. 1, д. 320, л. 7; Архив Главного управления памятников материальной культуры и музеев Министерства культуры РУз., Я $\frac{2332}{W 31}$, с. 3] (первая экспедиция, тогда ещё Туркомстариса, была в 1922 г., она подробно описана А.А. Семёновым) [Семёнов, 1926, с. 121-130]. В ней участвовали известный искусствоведориенталист Б.П. Денике и архитектор М.М. Логинов. М.М. Логинов сделал архитектурные обмеры и составил смету на ремонт мавзолея [Умняков, 1928 , с. 265 ; 1929 , с. 31]. «Экспедицией, - пишет И.И. Умняков, - были отмечены ремонтированные в новейшее время части и подтверждён факт незавершённости мечети* [*мавзолея Ясави - прим. авт.] в тимуровское время» [ЦГА РУз., ф. Р2810, оп. 1, д. 119, л. 29].

В 1927 г. были проведены небольшие подготовительные работы [ЦГА РУз., ф. Р2810, оп. 1, д. 119, л. 29]. Более полное описание ремонтов 1920-х гг. сделано в специальной работе Ю.А. Ёлгина [Ёлгин, 2013, с. 109-127]. Основной ремонт из-за недостатка денежных средств начался только в 1928 г. Продолжался он три года. На ремонт в 1928 г. было выделено 11000 руб., в 1929 г. - 5400 руб. Самый значительный объём работ был выполнен в 1928 г. Акт о приёмке-сдаче сделанного за этот период насчитывает 12 пунктов [ЦГА РУз., ф. Р2406, оп. 1, д. 481, лл. 1-2 об.]. Доклады, сделанные Н.М. Бачинским на заседаниях архитектурно-реставрационного Отделения Средазкомстариса (впослед- ствии Узкомстариса), отложившиеся в фондах Узкомстариса, архитекторов Б.Н. Засыпкина и Л.Ю. Маньковской (ЦГА РУз.), служат лучшим источником по этому периоду изучения и ремонтов мавзолея Ходжи Ахмеда Ясави (Н.М. Бачинский называл его «мечетью-ханакой»).

Работы 1920-х гг. на мавзолее Ясави ещё были далеки от понятия реставрации памятника архитектуры. Реставраторы, работавшие на памятнике в последующие периоды, определяли их суть в нескольких словах - «работы укрепительного характера с перекладкой аварийных сводов» [ЦГА РУз., ф. Р2406, оп. 1, д. 320, л. 7]. За этой оценкой стоит объём работ, превышающий по содержанию и значению всё, сделанное в первой половине XIX - первом десятилетии XX в.

Кудук-хана. Во всех докладах и отчётах, направляемых в Туркомстарис (Средазкомстарис-Узкомстарис), на первом месте стоит кудук-хана, потеснив более важные в архитектурном и идеологическом отношении планировочные узлы комплекса, такие, как Большой и Малый Ак-Сараи и даже мечеть в северо-западном углу здания. Это помещение с колодцем было закрыто комиссией Туркомстариса для посещения ещё в 1922 г. ввиду угрозы обрушения сводчатых перекрытий.

В кудук-хане проделан самый большой объём работ на комплексе, включающий радикальные мероприятия, приближающие капитальный ремонт к реставрации.

В 1928 г. здесь были разобраны четыре арки, снят и вновь восстановлен большой купол. Также отремонтирована панель внизу стен помещения и положены две арки - над две- 
рями и нишей* [*какой? - прим. авт.]. В интерьере кудук-ханы и в коридоре возле неё залиты алебастром и скреплены кольцевыми и квадратными железными скобами многочисленные трещины. Также «залиты трещины в наружной стене от окон до низа помещения» [ЦГА РУз., ф. Р2406, оп. 1, д. 320 , л. 25 об.; ЦГА РУз., ф. Р2406, оп. 1, Д. 481, л. 2].

Мечеть. Второй по экстренности противоаварийных мер композиционный блок мавзолея. Здесь переложена северная грань восьмерика, на который поставлен купол, и отремонтированы сталактиты в нише северной стены [ЦГА РУз., ф. Р2406, оп. 1, д. 320, л. 6; ЦГА РУз., ф. Р2406, оп. 1, Д. 481, л. 2].

Большой Ак-Сарай. По акту приёмки-сдачи от 07.10.1928 г. значится только заливка трещин [ЦГА РУз., ф. Р2406, оп. 1, д. 481, л. 2 об.]. Между тем, считал Н.М. Бачинский, в Большом Ак-Сарае требовался немалый и серьёзный ремонт. Деформации зафиксированы во всех сводах и куполах. Южная стена над входом осела, трещины в ней достигали 20 см в ширине. Но сметой была предусмотрена только заливка трещин и штукатурка поверхностей [ЦГА РУз., ф. Р2810, оп. 1, д. 114 , л. 6]. Позже он докладывал на заседании архитектурнореставрационного Отделения Узкомстариса о подводке фундамента под помещение Ак-Сарая* [*полагаем, имеется в виду Большой Ак-Сарай прим. авт.] [ЦГА РУз., ф. Р2406, оп. 1, д. 481, л. 1]. Выводы Н.М. Бачинского о фундаментах мавзолея Ходжи Ахмеда Ясави, сделанные ещё до повсеместного их вскрытия в 1950-х гг,, остры и интересны. Об этом он писал в 1929 г.: «...ввиду того, что линия соприкосновения стен с грунтом про- ходит зигзагами и носит явные следы выемки, напрашивается предположение, что фундамент был разобран в течение последних 2-3-х веков, так как ни одно из обнаруженных непосредственно под стенами погребений, по мнению М.Е. Массона, не может быть признано старше 200-250 лет» [ЦГА РУз., ф. Р2810, оп. 1, д. 114, л. 3]. Л.Ю. Маньковская подтвердила этот факт, добавив, что в исследовании фундаментов принимал участие M.Е. Массон [ЦГА РУз., ф. Р2810, оп. 1 , д. 16, л. 12].

Проводились в Большом АкСарае и другие, не менее кардинальные чем в кудук-хане, вмешательства в конструкции - разобраны и «заново положены» оба купола и три арки. При этом Н.М. Бачинский выяснил, что одна арка* [*не указано какая. прим. авт.] сложена «на воске с битым кирпичом» [ЦГА РУз., ф. Р2406, оп. 1, д. 481, л. 1].

Малый Ак-Сарай. В этом двусветном зале также были разобраны и укреплены две арки и произведена заливка трещин в сводах второго этажа. Ремонтировалась нижняя часть стены [ЦГА РУз., ф. Р2406, оп. 1, д. 320, л. 6; ЦГА РУз., ф. Р2406, оп. 1 , д. 481 , л. 2 об.].

Китапхана. Разобраны и переложены две арки. Заливка трещин в стенах. Нижние части помещеня укреплены кирпичом на алебастровом растворе [ЦГА РУз., ф. Р2406, оп. 1, д. 481, л. 2; ЦГА РУз., ф. Р2810, оп. 1, д. 119, л. 29].

Коридоры. В нескольких местах перекладывались аварийные своды [ЦГА РУз., ф. Р2406, оп. 1, д. 320, л. 6-7]. В коридоре между кудук-ханой и Малым Ак-Сараем на 2 этаже разобраны и заново положены своды, разобрана и переложена 
кровля над ними [ЦГА РУз., ф. Р2406, оп. 1 , д. 481 , л. 2 об.].

«Зиарат-хана». Так в документах иногда называли квадратное в плане сводчатое пространство в коридоре (или весь коридор) между мечетью и гурханой, имеющее низко поставленный проём с решёткой-панджарой, через которую виднеется внутреннее помещение усыпальницы. Аналогичное пространство симметрично расположено в коридоре между гурханой и Большим Ак-Сараем. В этом месте разобраны и вновь положены два свода [ЦГА РУз., ф. Р2810, оп. 1, д. 119, л. 30].

Пештак. Этим термином во всех документах 1920-х гг. обозначается главный, южный портал мавзолея, оставшийся недостроенным. По некоторым документам, работы 1928 г. лишь коснулись этого важнейшегов конструктивно-планировочном и архитектурно-смысловом отношении элемента комплекса. В действительности была сделана кирпичная выстилка поверху портала, а также «зашивка металлическим скобами трещин тыловых конструкций» [ЦГА РУз., ф. Р2810, оп. 1, д. 16, л. 12]. Скобы установлены с интервалом в 2 м сверху донизу конструкции [ЦГА РУз., ф. Р2406, оп. 1, д. 481, л. 2 об.]. Затронуты ремонтом минареты, фланкирующие пештак. Б.Н. Засыпкин упоминает «закладку ветхих мест кирпичом» [ЦГА РУз., ф. Р2406, оп. 1, д. 320, л. 5-7]. Сам же Н.М. Бачинский пишет, что были исправлены 84 ступени «в северном минарете»* [*так в тексте; в реальности же мы имеем дело с башнями-гульдаста, фланкирующими главный портал мавзолея, именуемыми традиционно ю.-з. и ю-в. минаретами - прим. авт.] с установкой рёбер из тополёвых до- сок [ЦГА РУз., ф. Р2810, оп. 1, д. 114, л. 5].

Кровля. Вызывала наибольшие опасения у дореволюционных инженеров и архитекторов, обследовавших памятник в начале XX в., а также у археолога Н.И. Веселовского. Н.М. Бачинский везде, где производил вмешательства в сводчатые и подкупольные конструкции, заботился об их защите от атмосферных явлений и ремонтировал участки кровли над ними [ЦГА РУз., ф. Р2406, оп. 1, д. 320, л. 25 об. 26]. Верхний, кирпичный слой кровли был также переложен у ребристого купола гурханы [ЦГА РУз., ф. Р2406, оп. 1, д. 481, л. 2 об.]. Спустя 30 лет как раз по отношению к кровле была высказана критика ремонта 1928 г. Л.Ю. Маньковская считала, что тогда повторили все ошибки ремонта кровли и куполов второстепенных помещений, проводившегося во второй половине 1880-х гг., а именно - заливки алебастровым раствором. В результате, по её мнению, работы 1928 г. «не имели должного эффекта» [ЦГА РУз., ф. Р2810, оп. 1, д. 16, л. 12]. Но у современников работы Н.М. Бачинского получили высокую оценку. Пятого сентября 1928 г. на заседании Средазкомстариса его член (впоследствии председатель этого Комитета) М.М. Цвибак сделал доклад о своей (совместно с Б.П. Денике, в ту пору директором Государственного музея восточных культур) командировке в г. Туркестан для осмотра работ на мавзолее Ходжи Ахмеда Ясави. Работа, константировал он, «выполнена безупречно, израсходована небольшая сумма и очень экономно» [ЦГА РУз., ф. Р2810, оп. 1, д. 114, л. 2].

Из-за недостатка средств ремонт в 1928-1930-х гг. в полном объёме выполнить не удалось. Но 
катастрофические разрушения на опасных участках были ликвидированы. Предложение Н.М. Бачинского переложить стены оседающего с.-з. блока мавзолея, где расположена мечеть («...Я полагал бы, - писал он, - более рациональным совершенную разборку упомянутых двух стен и их новую кладку» [ЦГА РУз., ф. Р2810, оп. 1, д. 114 , л. 6 об.]), было Средазкомстарисом отклонено, т.к. не были просчитаны уклоны внешних стен и их оседание [ЦГА РУз., ф. Р2406, оп. 1 , д. 320 , л. 7]. В целом местный и частный характер ремонта 1928 г. был продиктован аварийным состоянием отдельных конструктивных узлов здания.

Несомненно, исследователь и практик-реставратор такого уровня как Н.М. Бачинский не мог выступать лишь в роли прораба, надзирающего за ходом строительных работ. Первоочерёдные противоаварийные меры не исключали научно-исследовательское значение, которое имела экспедиция 1928 года в г. Туркестан. В ней принял деятельное участие М.Е. Массон, археолог и учёный широкого востоковедного профиля. Известно, что им в 1928 г. положено начало профессиональному археологическому изучению мавзолея Ясави [Смагулов, 1997 , с. 93-96; 2002, с. 237-241; Ёлгин, 2013, с. 109-127]. Однако М.Е. Массон также оказывал содействие H.M. Бачинскому в качестве историка среднеазиатской архитектуры. Имеются сведения, что он принимал непосредствнное участие в возобновлении купола кудук-ханы и других сводчатых перекрытий. Н.М. Бачинский докладывал в Средазкомстарис, что М.Е. Массоном и В.Л. Вяткиным было прочтено имя второго мастера - строителя мавзолея Ходжи Ахмеда
Ясави (первая строительная надпись прочитана М.-С. Бекчуриным в 1866 г. [Бекчурин, 1866, с. 209-217]). Архитектор передаёт её наверно: «Абдуали бен Ширази» [ЦГА РУз., ф. Р2406, оп. 1, д. 481, л. 1]. Очевидно, речь Н.М. Бачинский ведёт о шестиугольной плитке с куфической надписью, помещённой в верхний поясок майоликового бордюра ребристого купола гурханы. Её, по словам М.Е. Массона, обнаружил в 1925 г. «один туркестанский любознательный шейх» [Mассон, 1929, с. 44]. Этот «автограф» строителя мавзолея Ясави имеет ряд вариантов чтения (М.Е. Массон и В.Л. Вяткин, А.А. Иванов, Б.Т. Туякбаева).Последнийперевод, сделанный А.К. Муминовым, звучит так: «Работа зодчего Шамс Абд ал-Ваххаба Ширази» [Мавзолей Ходжа Ахмада Йасави, 2011, с. 95]. Изучение в 1928 г. M.Е. Массоном этой надписи имело принципиальное значение, поскольку именно Абд ал-Ваххабе приписывается общий замысел композиционнопространственного решения всего комплекса или, по крайней мере, авторство усыпальницы [Массон, 1929, c. 45 ; Бакланов, 1947, с. 63$]$.

$$
\text { Круг научных интересов }
$$

Н.М. Бачинского в области среднеазиатской архитектуры в те годы определялся двумя проблемами - использованием дерева в конструкциях и декоре средневековых зданий и вопросами сейсмостойкости различных сооружений. Этим, возможно, объясняется отсутствие у него публикаций по мавзолею Ясави. Это блестяще сделал М.Е. Массон. В 1929 г. вышла из печати его статья «О постройке мавзолея Ходжа Ахмеда в городе Туркестане», год спустя - монографическая брошюра «Мавзолей Ходжа Ахмеда Ясеви» [Массон, 1929; 1930]. 
Полагаем, появление этих публикаций, на которые по сей день ссылаются все исследователи памятника, стало возможным благодаря совместной работе с Н.М. Бачинским в 1928 г. Бо- лее благоприятный период в истории памятника наступит в 1938 г., когда можно было переходить от экстренных ремонтов к вопросам научной реставрации.

\section{ЛИТЕРАТУРА}

1. Бакланов Н.Б. Три сооружения Тимура // Труды Всероссийской Академии художеств. М.; Л.: «Искусство», 1947. Вып. І. С. 51-66.

2. Бекчури M.-С. Описание мечети Азрета, находящейся в городе Туркестане // Военный сборник. 1866. № 8. С. 209-217.

3. Вопросы изучения и реставрации памятника архитектуры «Ахмед Ясеви» в г. Туркестане в связи с Генеральной реставрацией 1952-1956 гг. // ЦГА РУз., ф. Р2406, оп. 1 , д. 320.

4. Длужневская Г.В. Археологические исследования в Центральной Азии и Сибири в 1859-1959гг (по материалам Научного архива ИИМК РАН). СПб.: ЭлекСис, 2011. $246 \mathrm{c}$.

5. Ёлгин Ю.А. Археологические и историко-архитектурные исследования мавзолея Ходжи Ахмеда Ясави: вторая половина ХІХ в. - середина 1950-х годов: (Очерки и материалы). Алматы, 2013. 225 c.

6. Копии с документов по ремонтно-реставрационным работам в комплексе Ахмеда Ясави, произведенным в 1928 г. архитектором Бачинским Н.М. // ЦГА РУз., ф. Р2810, оп. 1, д. 114.

7. Мавзолей Ходжа Ахмада Йасави / А.К. Муминов, М. Кожа, С. Молдаканагатулы. Алматы: «Эффект» ЖШС, 2011. 208 с. Изд. 3-е, перераб. и доп.

8. Маньковская Л.Ю. Ремонты и реставрация мавзолея Ахмада Яссави в городе Туркестане Казахской ССР // ЦГА РУз., ф. Р2810, оп. 1, д. 16.

9. Массон М.Е. О постройке мавзолея Ходжа Ахмеда в городе Туркестане // Известия Среднеазиатского географического общества. 1929. Т. ХІХ. С. 39-45.

10. Массон M.E. Мавзолей Ходжа Ахмеда Ясеви. Ташкент: Типо-тит. № 2 Узполигафтреста, $1930.22 \mathrm{c}$.

11. Протокол заседания Средазкомстариса по ремонту мечети Ходжа Ахмеда Ясави // ЦГА РУз., ф. Р2406, оп. 1, д. 481.

12. Сборник материалов по обследованию храма Ходжа Ахмеда Ясави за время с 1922 по 1945 г. // ЦГА РУз., ф. Р2810, оп. 1, д. 119.

13. Семёнов A.А. Мечеть Ходжи Ахмеда Есевийского в г. Туркестане: Результаты осмотра в ноябре 1922 г. // Известия Средазкомстариса. 1926. Вып. I. С. 121-130.

14. Смагулов Е.А. Михаил Евгеньевич Массон и археология Туркестана // Новости археологии. 1997. С. 93-96.

15. Смагулов Е.А. М.Е. Массон и археология Туркестана // Культурное наследие Средней Азии. Ташкент, 2002. С. 237-241.

16. Умняков И.И. Архитектурные памятники Средней Азии. Исследования. Ремонт. Реставрация. 1920-1928 гг. Ташкент, 1929. 40 с.

17. Умняков И.И. Археологичесская и ремонтно-реставрациооная работа Средазкомстариса в 1927 году // Известия Средазкомстариса. 1928. Вып. III. С. 265-275.

18. Шахурин К.A. Научно-археологический отчёт по работам на памятнике архитектуры Ходжа-Ахмед-Ясеви в г. Туркестане в 1952 году // Архив Главного управления памятников материальной культуры и музеев Министерства культуры РУз., Я $\frac{2332}{W 31}$. 


\title{
Сведения об авторе
}

Ёлгин Юрий Андреевич - старший научный сотрудник, Институт археологии им. А.Х. Маргулана (Алматы, Казахстан); уolginuriy@gmail.com

\section{Н.М. БАЧИНСКИЙ. 1928 ЖЫЛҒЫ ҚОЖА АХМЕТ ЯСАУИ КЕСЕНЕСІНДЕГІ ЖӨНДЕУ ЖҰМЫСТАРЫ}

\author{
Ю.А. Ёлгин
}

1928-30-шы жылдары Түркістандағы Қожа Ахмет Ясауи кесенесіне шұғыл апаттарға қарсы шаралар сипатындағы айтарлықтай біраз жөндеу жұмыстары жүргізілді. Басты жөндеу және зерттеу жұмыстары 1928 ж. жүрді. Оларды осы мақсатта Ленинград Мемлекеттік қалпына келтіру шеберханасының Түркістанға арнайы жіберген, ортаазиялық сәулет өнерінің зерттеушісі және қалпына келтіру ісінің білгірі архитектор Н.М. Бачинский басқарды. Өзбекстан Республикасының Орталық мемлекеттік архивінде (Ташкент) сақталған Н.М. Бачинскийдің баяндамалары мен есептері, сондай-ақ өзге де құжаттар бойынша осы уақытқа дейін Ясауи кесенесіне жүргізілген жөндеу жұмыстары, қалпына келтіру мен зерттеулер туралы белгісіз болып келген парақтары болып табылатын жөндеу жұмыстарының барысы мен мазмұны ашылады.

Түйін сөздер: археологиялық зерттеулер, Қожа Ахмет Ясауи кесенесі, Н.М. Бачинский, М.Е. Массон, жөндеу, Ақ-Сарай, құдықхана, мешіт, пештак

\section{N.M. BACHINSKY. REPAIR of MAUSOLEUM of KHOJA AHMED YASAWI in 1928}

\section{Yu.A. Yolgin}

In 1928-1930 was carried out a significant repair of Mausoleum of Khoja Ahmed Yasawi in Turkestan having nature of emergency response measures. The bulk of repair and research works was in 1928. It was headed by the researcher of Central Asian architecture and practitioner of restoration issues architect N.M. Bachinsky, sent to this purpose to Turkestan by the Leningrad State Restoration Workshops. Course and content of the repair, which is almost an unexplored page in the history of repairs, restoration and study of the Yasawi Mausoleum, is disclosed on the basis of reports and statements of N.M. Bachinsky, as well as other documents stored in the Central State Archive of the Republic of Uzbekistan (Tashkent).

Keywords: archaeological investigations, mausoleum of Khoja Ahmed Yasawi, N.M. Bachinsky, M.Ye. Masson, repair, Ak-Saray, kuduk-khana, mosque, peshtak

\section{REFERENCES}

1. Baklanov, N. B. 1947. In Trudy Vserossiiskoi Akademii hudozhestv (Proceedings of the All-Russian Academy of Arts). Moscow; Leningrad: «Iskusstvo» Publ., 51-66 (in Russian).

2. Bekchurin, M. S. 1866. In Voennyi sbornik (Military collection), 8, 209-217 (in Russian).

3. In TsGA RUz. (Central State Archive of the Republic of Uzbekistan), f. R2406. op. 1, d. 320 (in Russian).

4. Dluzhnevskaya, G. V. 2011. Arheologicheskie issledovaniya v Centralnoi Azii $i$ Sibiri v 1859-1959 (Archaeological research in Central Asia and Siberia in 1859-1919). Saint Petersburg: "ElekSis” Publ. (in Russian). 
5. Yolgin, Yu. A. 2013. Arheologicheskie i istoriko-arhitekturnye issledovaniya mavzoleya Hodzhi Ahmeda Yasavi: vtoraya polovina XIX - seredina 1950 godov (Archaeological and historical-architectural investigations of Mausoleum of Khoja Ahmed Yasawi: Second half of XIX century - Middle of 1950's). Almaty (in Russian).

6. In TsGA RUz. (Central State Archive of the Republic of Uzbekistan), f. R2810, op. 1, d. 114 (in Russian).

7. Muminov, A. K., Kozha, M., Moldakanagatuly, S. 2011. Mausoleum of Khoja Ahmed Yasawi. Almaty: "Effect" Publ. - $3^{\text {rd }}$ ed. (in Russian)

8. Mankovskaya, L. Yu. In TsGA RUz. (Central State Archive of the Republic of Uzbekistan), f. R2810, op. 1, d. 16. (in Russian).

9. Masson, M. Ye. 1929. In Izvestiya Sredneaziatskogo geograficheskogo obshchestva (News of Central Asian Geographical Society), XIX, 39-45 (in Russian).

10. Masson, M. Ye. 1930. Mausoleum of Khoja Ahmed Yasawi. Tashkent: "Uzpoligraphtrest" Publ. (in Russian).

11. In TsGA RUz. (Central State Archive of the Republic of Uzbekistan), f. R2406, op. 1, d. 481 (in Russian).

12. In TsGA RUz. (Central State Archive of the Republic of Uzbekistan), f. R2810, op. 1, d. 119 (in Russian).

13. Semyonov, A. A. 1926. In Izvestiya Sredazkomstarisa (News of Central Asian Committee on the issues of museums, preservation of ancient buildings, art and nature), I, 121-130 (in Russian). Russian).

14. Smagulov, Ye. A. 1997. In Novosti arheologii (News of archaeology), 93-96 (in

15. Smagulov, Ye. A. 2002. In Kulturnoe nasledie Srednei Azii (Cultural heritage of Central Asia). Tashkent, 237-241(in Russian).

16. Umnyakov, I. I. 1928. In Izvestiya Sredazkomstarisa (News of Central Asian Committee on the issues of museums, preservation of ancient buildings, art and nature), III, 265-275 (in Russian).

17. Umnyakov, I. I. 1929. Arhitekturnye pamyatniki Srednei Azii. Issledovaniya. Remont. Restavraciya. 1920-1928 (Architectural monuments of Central Asia: Investigations. Repair. Restoration. 1920-1928). Tashkent (in Russian).

18. Shakhurin, K. A. In Archive of the Chief administration of monuments of material culture and museums of the Ministry of Culture RUz., Ya $\frac{2332}{W 31}$. (in Russian)

\section{About the Author:}

Yolgin Yuri A. Senior Researcher, A.Kh. Margulan Archeology Institute, Almaty, Kazakhstan; yolginuriy@gmail.com

\footnotetext{
Мүдделер қақтығысы туралы ақпаратты ашу. Автор мүдделер қақтығысының жоқтығын мәлімдейді.

/ Раскрытие информации о конфликте интересов. Автор заявляет об отсутствии конфликта интересов.

/ Disclosure of conflict of interest information. The author claim no conflict of interest.

Мақала туралы ақпарат / Информация о статье / Information about the article.

Редакцияға түсті / Поступила в редакцию / Entered the editorial office: 29.01.2019.

Рецензенттер мақұлдаған / Одобрено рецензентами / Approved by reviewers: 05.02.2019.

Жариялауға қабылданды / Принята к публикации / Accepted for publication: 12.02.2019.
} 